\title{
The ability of common mastitis-causing pathogens to survive an ensiling period
}

\author{
C. S. Petersson-Wolfe ${ }^{\star 1}{ }^{1}$ S. Masiello, ${ }^{*}$ and J. S. Hogan† \\ *Department of Dairy Science, Virginia Tech, Blacksburg 24061 \\ †Department of Animal Science, The Ohio State University, Wooster 44691
}

\begin{abstract}
A forage-based study was conducted to examine the ability of enterococci, streptococci, and gram-negative bacteria to survive a 3 -wk ensiling process. Harvested grass and corn forages were each divided into 3 treatment groups consisting of 2 commercially available silage inoculants and 1 negative control group. Within $24 \mathrm{~h}$ of harvest, a uniform amount of forage was added to each of 18 vacuum-sealable freezer bags. Inoculants 1 and 2 were applied to each of 6 bags and the remaining 6 bags were not inoculated (negative control). All bags were sealed using an industry-grade vacuum sealer to create a pillow pack. At wk 1,2, and 3 of the ensiling process, 6 bags were opened, 2 from each of the 3 groups. Dry matter (DM), pH, and bacterial enumeration were determined on the forage before ensiling, as well as at wk 1,2, and 3 of ensiling. The $\mathrm{pH}$ of grass and corn samples decreased to 5.2 and 4.1, respectively, by the end of the ensiling period. Inoculant $2\left(7.3 \log _{10}\right.$ $\mathrm{cfu} / \mathrm{g}$ of DM) resulted in a greater enterococcal count in grass samples than did inoculant $1\left(4.2 \log _{10} \mathrm{cfu} / \mathrm{g}\right.$ of DM) at 3 wk of ensiling and both were greater than the negative control $\left(1.2 \log _{10} \mathrm{cfu} / \mathrm{g}\right.$ of DM). Counts of streptococci in grass samples at wk 3 were greater in inoculated samples (inoculant 1, $7.6 \log _{10} \mathrm{cfu} / \mathrm{g}$ of DM; inoculant 2, $7.0 \log _{10} \mathrm{cfu} / \mathrm{g}$ of DM) compared with the negative control $\left(4.3 \log _{10} \mathrm{cfu} / \mathrm{g}\right.$ of $\left.\mathrm{DM}\right)$. Treatment differences were observed following $1 \mathrm{wk}$ of ensiling in corn samples. Enterococcal counts on corn samples following the 3 -wk ensiling were not significantly different between inoculant 1 ( $4.3 \log _{10} \mathrm{cfu} / \mathrm{g}$ of $\left.\mathrm{DM}\right)$ and inoculant $2\left(4.4 \log _{10} \mathrm{cfu} / \mathrm{g}\right.$ of DM). However, counts in both inoculated groups were greater than in the negative control group (4.0 $\log _{10} \mathrm{cfu} / \mathrm{g}$ of DM). No significant treatment differences were observed for streptococci counts at wk 3. Counts for gram-negative bacteria were not detectable by wk 3 of ensiling in either grass or corn samples. The addition of a silage inoculant led to
\end{abstract}

Received March 1, 2011.

Accepted June 27, 2011.

${ }^{1}$ Corresponding author:milk@vt.edu greater counts of enterococci and streptococci in grass silage compared with the negative control at the end of a 3 -wk ensiling period. The application of a silage inoculant led to increased enterococci counts, but not streptococci counts, in corn samples following the ensiling period. These data indicate that enterococci and streptococci are able to survive the $\mathrm{pH}$ decrease observed during ensiling.

Key words: Enterococcus, silage, inoculant

\section{INTRODUCTION}

Enterococci and streptococci are pathogens that result in environmental mastitis (Sobiraj et al., 1997), a disease estimated to cost the United States dairy industry nearly $\$ 2$ billion annually (Harmon, 1994). These organisms are facultatively anaerobic, gram-positive cocci that occur singly, in pairs (enterococci), or in chains (streptococci) (Schleifer and Kilpper-Balz, 1984; Gilmore, 2002). Streptococcal species do not produce catalase, whereas some enterococcal species produce a pseudocatalase and display weak effervescence in the presence of hydrogen peroxide. Although these bacteria possess an optimum growth temperature of $35^{\circ} \mathrm{C}$, growth can occur between 10 and $45^{\circ} \mathrm{C}$. Similarly, streptococci and enterococci can survive in a wide range of $\mathrm{pH}$ values, yet differences between species have been noted (Martinez-Murcia and Collins, 1991). Despite the vast knowledge regarding the growth parameters of these bacteria, control of these pathogens in the environment and subsequent mastitis remains a daunting task. By gaining a more complete understanding of primary sources of these organisms on dairy farms, we can devise more appropriate control recommendations to reduce exposure of cows to potential mastitis pathogens.

One known source of enterococci is the bacterial community of the human gastrointestinal tract $\left(10^{5}\right.$ to $10^{7}$ cfu of enterococci per mL of stool; Kayser, 2003). These organisms have been implicated in the emerging prominence of nosocomial infections, the prevalence of resistance to commonly used antibiotics, and the shared virulence traits expressed by isolates from hos- 
pital patients and isolates from food animals (Mannu et al., 2003). With prominent publications on antimicrobial resistance (Leng et al., 1997; Paulsen et al., 2003) and other potentially important virulence traits of enterococci (Clewell, 1993; Jett et al., 1994; Olmsted et al., 1994), concern is growing about the application of human wastewater to crop fields supplying animal feed. Two recent studies examined the route of transmission of antibiotic-resistant enterococci in Sweden. A longitudinal study showed similar antibiotic resistance in strains of Enterococcus faecium from hospital sewage, treated sewage, untreated sewage, and surface water. At that time, resistance to antibiotics was rare in isolates from animals, excluding animals from the transmission cycle of antibiotic resistant enterococci (Iversen et al., 2004). A more recent study by Sahlström et al. (2009) reported widespread occurrence of vancomycinresistant enterococci (VRE) in treated sewage sludge. However, similar strains were not found in chickens, further refuting that animals are the origin of antibiotic resistance enterococci. Therefore, application of treated sewage on arable farmland may serve as a source of enterococci on farm and be implicated in transmission of antimicrobial resistance to farm animals (Sahlstrom et al., 2009) through consumption of contaminated feeds. Additionally, because these organisms do not adequately colonize the adult ruminant gastrointestinal tract (Devriese et al., 1992), the ingested enterococci may be excreted in fecal matter. As known mastitis pathogens, enterococci in the cow's environment draw particular concern for a variety of reasons. Following exposure of the udder to the fecal matter, the enterococci may gain entry to the mammary gland through the teat canal, resulting in colonization and subsequent infection.

In a survey conducted to examine potential bovine sources of enterococci, E. faecium was found in bedding, milk, and feed (Petersson-Wolfe et al., 2008). Enterococci are often associated with plant matter; however, some Enterococcus spp., such as E. faecium, are commonly included in commercially available silage inoculants used to preserve the nutrient value of feed during ensiling (Cai, 1999). Whether the use of silage inoculants containing enterococci contributes to an increased environmental presence on dairy operations remains unclear. Previous work examined the ability of Enterococcus spp. (obtained from the United Kingdom National Culture Collection) to survive on forages. Results showed that enterococci are present in an inoculated forage crop for at least $4 \mathrm{wk}$ (Mackey and Hinton, 1990). However, no reported studies have examined the presence of mastitis-causing pathogens, particularly enterococci strains, from commercially available silage inoculants following ensiling. Thus, the objective of the current study was to examine the ability of mastitiscausing bacteria to survive an ensiling period following the application of a commercially available silage inoculant.

\section{MATERIALS AND METHODS}

\section{Forage Harvest}

Grass and corn crops were harvested with farm equipment at the Virginia Tech Dairy Center (Blacksburg) in fall 2008. The forages were placed into large, clean containers and were transported to the laboratory for ensiling immediately post-harvest. In the laboratory, nylon/polyethylene 3-mil high-performance film vacuum pouches $(40 \times 65 \mathrm{~cm}$; Bunzl-Koch Supplies, Kansas City, MO) were assigned to 1 of 3 treatments and used as ensiling bags for the study. The treatment groups consisted of 2 different commercially available silage inoculants and 1 negative control (noninoculated) group. Harvested forage was mixed thoroughly and a representative sample of grass was placed into each of 18 ensiling bags $(2,700 \mathrm{~g} / \mathrm{bag})$. This process was repeated for corn samples $(4,095 \mathrm{~g} / \mathrm{bag})$. For each forage type, the target weight was based on the maximum volume in each bag.

\section{Silage Inoculants and Ensiling Procedures}

The 2 commercially available silage inoculants contained E. faecium, and will be referred to as inoculant 1 and inoculant 2. According to manufacturer specifications, inoculant 1 contained $2.1 \times 10^{9} \mathrm{cfu} / \mathrm{g}$ of E. faecium. The amount of E. faecium contained in inoculant 2 was not specified, although the presence of E. faecium, along with other lactic acid-producing bacteria, was declared on the label as $2.0 \times 10^{9} \mathrm{cfu} / \mathrm{g}$. Prior to the start of the study, an enumeration of enterococcal counts in each inoculant was calculated in the laboratory. Inoculants were applied according to manufacturer's directions and adjusted for the volume of forage within each bag.

Inoculant 1 was applied to 6 bags $(0.027$ and $0.041 \mathrm{~g} /$ bag for grass and corn samples, respectively), inoculant 2 was applied to 6 bags $(0.001$ and $0.002 \mathrm{~g} / \mathrm{bag}$ for grass and corn samples, respectively), and the remaining 6 bags were not inoculated but immediately sealed to serve as negative controls. For bags receiving 1 of the 2 inoculant treatments, the calculated inoculant amount was suspended in $10 \mathrm{~mL}$ of sterile PBS, and the entire amount was applied into the bag with a polyethylene wash bottle. The forage was then mixed with a gloved hand for even coverage and the bag was sealed.

All bags were sealed using a Koch Ultravac Sealer (Bunzl-Koch Supplies) and a nitrogen tank. The pillow- 
pack setting was used to mimic silage stored in a bag on-farm. This process included a vacuum of $96 \%$, a vacuum plus for $10 \mathrm{~s}$, a heat seal for $0.7 \mathrm{~s}$, and a gas setting of $10 \%$ to result in a mix of $10 \%$ general atmosphere and $90 \%$ nitrogen gas within each bag. Once sealed, bags were checked for leaks or punctures. Bags were held at room temperature $\left(21^{\circ} \mathrm{C}\right)$ until the designated week of opening. At $1 \mathrm{wk}$ post-ensiling, 6 bags were opened, 2 from each of the 3 treatment groups. This process was repeated at wk 2 and 3 . Following the 3 -wk ensiling period, a sample from each treatment group was sent to Cumberland Valley Analytical Services Inc. (Hagerstown, MD) for standard forage analysis.

\section{Forage Sample Analysis}

On the first day of the designated week of opening, assigned bags were taken from the storage space and brought to the laboratory. Using a modified-atmosphere packaging (MAP) gas analyzer, each bag was punctured with the small probe and levels of $\mathrm{O}_{2}$ and $\mathrm{CO}_{2}$ were recorded. A total of $10 \mathrm{~g}$ of sample was suspended in $90 \mathrm{~mL}$ of sterile distilled water, and the $\mathrm{pH}$ of the aqueous phase was recorded (Accu-pHast, Fisher Scientific, Pittsburgh, PA). Twenty-five grams of each sample was placed in a convection oven at $100^{\circ} \mathrm{C}$ for $24 \mathrm{~h}$ to determine the DM content. Bacterial populations were enumerated by adding $10 \mathrm{~g}$ of sample to $90 \mathrm{~mL}$ of sterile PBS (pH 7.4) and mixing for $60 \mathrm{~s}$ in a stomacher (Stomacher 400 Circulator, Seward, UK). Serial dilutions of the liquid phase in sterile PBS were plated on the surface of kanamycin esculin azide agar (EMD Chemicals, Gibbstown, NJ), MacConkey agar (Becton Dickinson Microbiology Systems, Cockeysville, MD), MacConkey-inositol-carbenicillin agar (MCIC), and modified Edwards agar containing $5 \mathrm{mg} / \mathrm{L}$ of colistin sulfate and $2.5 \mathrm{mg} / \mathrm{L}$ of oxolinic acid (Becton Dickinson Microbiology Systems). Inositol (10 mg/L; Sigma Chemical Co., St. Louis, MO) and carbenicillin $(75 \mathrm{mg} / \mathrm{L}$; Pfizer Co., New York, NY) were added to the MacConkey agar for the MCIC. Bovine plasma $(50 \mathrm{~mL} / \mathrm{L})$ was substituted for whole blood to prepare the modified Edwards media. Serial dilutions plated on all media were $1: 10^{2}$ to $1: 10^{6}$. Inoculated plates were incubated for $24 \mathrm{~h}$ at $37^{\circ} \mathrm{C}$. Colonies were identified as enterococci (Hogan and Smith, 1997; Petersson-Wolfe et al., 2009), gram-negative bacteria (total grown on MacConkey agar), coliforms (lactose-positive colonies on MacConkey agar), Klebsiella spp. (pink to red colonies on MCIC), and streptococci (total growth on modified Edwards agar). Standard biochemical tests, including Gram stain, catalase test, Christie, Atkins, Munch-Petersen (CAMP) test, esculin hydrolysis test, and growth on high salt media, were performed to con- firm presumptive identification of enterococcal isolates selected from kanamycin esculin azide agar. Bacteria counts were expressed as $\log _{10}$ colony-forming units per gram of forage. The lowest detection limit was $1.0 \times$ $10^{3} \mathrm{cfu} / \mathrm{g}$. Microbial analysis was performed on grass and corn forages before ensiling (wk 0) and on samples from all bags at wk 1, 2, and 3 .

\section{Data Management and Statistical Analyses}

Statistical analyses were performed using SAS software, version 9.2 (SAS Institute Inc., Cary, NC). Main outcome variables included bacterial counts (total gram-negative, total lactose-positive, Klebsiella spp., Streptococcus spp., and Enterococcus spp.) and $\mathrm{pH}$ for both corn and grass samples. A MIXED procedure with repeated measures was run, with bag within treatment as the repeated variable for each week with the following model:

$$
\mathrm{Y}_{\mathrm{ijk}}=\mu+\mathrm{T}_{\mathrm{i}}+\mathrm{B}_{(\mathrm{i}) \mathrm{j}}+\mathrm{W}_{\mathrm{k}}+\mathrm{WT}_{\mathrm{ik}}+\mathrm{e}_{\mathrm{ijk}},
$$

where $Y_{i j k}=$ dependent variable; $\mu=$ mean of $Y ; T_{i}=$ effect of treatment ( $\mathrm{i}=1$ to 3 ); $\mathrm{B}_{(\mathrm{i}) \mathrm{j}}=$ effect of ensiling bag within treatment $(\mathrm{j}=1$ to 2$) ; \mathrm{W}_{\mathrm{k}}=$ effect of week of ensiling ( $\mathrm{k}=1$ to 3$)$; $\mathrm{WT}_{\mathrm{ik}}=$ interaction of week of ensiling and treatment; and $e_{i j k}=$ error (bag within treatment and week interaction).

To account for multiple pairwise comparisons, Tukey adjustments were performed on the main effects of week and treatment and on the treatment $x$ week interactions, with week as the slice. Additionally, contrasts were done between treatments at each week. Significance was declared at $P \leq 0.05$.

\section{RESULTS}

\section{Descriptive Results}

Laboratory enterococcal enumeration yielded values of $1.7 \times 10^{9} \mathrm{cfu} / \mathrm{g}$ and $1.3 \times 10^{8} \mathrm{cfu} / \mathrm{g}$ for inoculants 1 and 2, respectively. At the end of the 3 -wk ensiling period, grass and corn silage bags displayed $\mathrm{O}_{2}$ levels ranging from 3.7 to $4.8 \% \mathrm{O}_{2}$ and 6.6 to $6.9 \% \mathrm{O}_{2}$, respectively. The $\mathrm{CO}_{2}$ levels for the negative control, inoculant 1 , and inoculant 2 grass bags ranged from 26.1 to $39.9 \%, 27.6$ to $28.3 \%$, and 27.2 to $34.3 \%$, respectively. Within the corn silage treatments, the negative control bags and inoculant 2 bags had $\mathrm{CO}_{2}$ levels ranging from 25.6 to $35.1 \%$ and 18.8 to $31.8 \%$, respectively. Levels in the inoculant 1 corn bags ranged from 27.9 to $37.8 \%$ $\mathrm{CO}_{2}$. Changes in $\mathrm{pH}$ for grass and corn silages are shown in Table 1. A treatment $\times$ week interaction was shown for the $\mathrm{pH}$ of grass samples $(P<0.01)$. In wk 
Table 1. Bacterial enumeration of gram-negative bacteria, lactose-positive bacteria, Klebsiella spp., Streptococcus spp., and Enterococcus spp. from grass and corn samples assigned to 1 of 3 treatment groups during a 3-wk ensiling period

\begin{tabular}{|c|c|c|c|c|c|c|c|}
\hline \multirow[b]{2}{*}{$\begin{array}{l}\text { Sample } \\
\text { and week }\end{array}$} & \multirow[b]{2}{*}{ Treatment $^{1}$} & \multirow[b]{2}{*}{$\mathrm{pH}$} & \multicolumn{5}{|c|}{ Count $\left(\log _{10} \mathrm{cfu} / \mathrm{g}\right.$ of DM) } \\
\hline & & & $\begin{array}{c}\text { Total } \\
\text { gram-negative }\end{array}$ & Coliforms & $\begin{array}{l}\text { Klebsiella } \\
\text { spp. }\end{array}$ & $\begin{array}{l}\text { Streptococcus } \\
\text { spp. }\end{array}$ & $\begin{array}{c}\text { Enterococcus } \\
\text { spp. }\end{array}$ \\
\hline 0 & None & $7.2 \pm 0.0$ & $7.3 \pm 0.4$ & $\mathrm{ND}^{2}$ & $7.3 \pm 0.4$ & $5.1 \pm 0.4$ & $6.1 \pm 0.0$ \\
\hline \multirow[t]{2}{*}{1} & Neg C & $5.6 \pm 0.1^{\mathrm{a}}$ & $5.4 \pm 0.1^{\mathrm{a}}$ & $5.2 \pm 0.1^{\mathrm{a}}$ & $3.7 \pm 2.0^{\mathrm{a}}$ & $8.1 \pm 0.0^{\mathrm{a}}$ & $8.0 \pm 0.2^{\mathrm{a}}$ \\
\hline & I1 & $5.4 \pm 0.1^{\mathrm{a}}$ & $\mathrm{ND}^{\mathrm{b}}$ & $\mathrm{ND}^{\mathrm{b}}$ & $\mathrm{ND}^{\mathrm{b}}$ & $6.7 \pm 0.2^{\mathrm{a}}$ & $6.8 \pm 0.1^{\mathrm{a}}$ \\
\hline \multirow{2}{*}{2} & I1 & $4.9 \pm 0.0^{\mathrm{a}}$ & $\mathrm{ND}^{\mathrm{a}}$ & $\mathrm{ND}^{\mathrm{a}}$ & $\mathrm{ND}^{\mathrm{a}}$ & $6.3 \pm 0.6^{\mathrm{a}}$ & $5.6 \pm 1.6^{\mathrm{a}}$ \\
\hline & $\mathrm{I} 2$ & $6.4 \pm 0.0^{\mathrm{b}}$ & $4.9 \pm 2.6^{\mathrm{b}}$ & $4.9 \pm 2.6^{\mathrm{b}}$ & $3.2 \pm 1.7^{\mathrm{b}}$ & $6.4 \pm 0.3^{\mathrm{a}}$ & $6.9 \pm 0.3^{\mathrm{a}}$ \\
\hline \multirow[t]{3}{*}{3} & Neg C & $5.1 \pm 0.1^{\mathrm{a}}$ & $\mathrm{ND}^{\mathrm{a}}$ & $\mathrm{ND}^{\mathrm{a}}$ & $\mathrm{ND}^{\mathrm{a}}$ & $4.3 \pm 2.3^{\mathrm{b}}$ & $1.2 \pm 1.2^{\mathrm{a}}$ \\
\hline & I1 & $5.1 \pm 0.2^{\mathrm{a}}$ & $\mathrm{ND}^{\mathrm{a}}$ & $\mathrm{ND}^{\mathrm{a}}$ & $\mathrm{ND}^{\mathrm{a}}$ & $7.6 \pm 1.0^{\mathrm{a}}$ & $4.2 \pm 1.8^{\mathrm{b}}$ \\
\hline & $\mathrm{I} 2$ & $5.2 \pm 0.1^{\mathrm{a}}$ & $\mathrm{ND}^{\mathrm{a}}$ & $\mathrm{ND}^{\mathrm{a}}$ & $\mathrm{ND}^{\mathrm{a}}$ & $7.0 \pm 0.3^{\mathrm{a}}$ & $7.3 \pm 0.1^{\mathrm{c}}$ \\
\hline \multicolumn{8}{|l|}{ Corn } \\
\hline 0 & None & $7.0 \pm 0.0$ & $8.3 \pm 0.1$ & $7.9 \pm 0.6$ & $8.2 \pm 0.1$ & $5.5 \pm 0.2$ & $6.9 \pm 0.0$ \\
\hline 2 & $\mathrm{I} 2$ & $3.9 \pm 0.0^{\mathrm{a}}$ & $\mathrm{ND}^{\mathrm{a}}$ & $\mathrm{ND}^{\mathrm{a}}$ & $\mathrm{ND}^{\mathrm{a}}$ & $4.1 \pm 0.1^{\mathrm{a}}$ & $3.9 \pm 0.1^{\mathrm{a}}$ \\
\hline \multirow[t]{3}{*}{3} & Neg C & $4.1 \pm 0.0^{\mathrm{a}}$ & $\mathrm{ND}^{\mathrm{a}}$ & $\mathrm{ND}^{\mathrm{a}}$ & $\mathrm{ND}^{\mathrm{a}}$ & $4.1 \pm 0.1^{\mathrm{a}}$ & $4.0 \pm 0.1^{\mathrm{a}}$ \\
\hline & I1 & $4.1 \pm 0.0^{\mathrm{a}}$ & $\mathrm{ND}^{\mathrm{a}}$ & $\mathrm{ND}^{\mathrm{a}}$ & $\mathrm{ND}^{\mathrm{a}}$ & $4.2 \pm 0.1^{\mathrm{a}}$ & $4.3 \pm 0.1^{\mathrm{b}}$ \\
\hline & $\mathrm{I} 2$ & $4.0 \pm 0.0^{\mathrm{a}}$ & $\mathrm{ND}^{\mathrm{a}}$ & $\mathrm{ND}^{\mathrm{a}}$ & $\mathrm{ND}^{\mathrm{a}}$ & $4.1 \pm 0.1^{\mathrm{a}}$ & $4.4 \pm 0.1^{\mathrm{b}}$ \\
\hline
\end{tabular}

\footnotetext{
${ }^{\mathrm{a}-\mathrm{c}}$ Values with different superscript letters are significantly different $(P<0.05)$ within treatment group and week

${ }^{1}$ Treatment groups consisted of a negative control group (Neg C; noninoculated forage) and 2 commercially available silage inoculants (I1 and I2).

${ }^{2} \mathrm{ND}=$ bacterial count below detection limit $(<1,000 \mathrm{cfu} / \mathrm{g}$ of $\mathrm{DM})$.
}

2 , inoculant 2 displayed a significantly higher $\mathrm{pH}(6.4)$ than either inoculant 1 (4.9) or the negative control (5.3). No significant treatment effect was seen for corn samples. However, the $\mathrm{pH}$ of corn samples did show a significant decrease over the course of the study $(P<$ 0.01). Standard forage analyses yielded results typical of haylage and corn silage (data not shown).

\section{Microbial Enumeration}

All results of bacterial enumeration and $\mathrm{pH}$ are shown in Table 1. For grass samples, a significant interaction of treatment $\times$ week was observed for all counts of gram-negative bacteria (total gram-negative, coliforms, and Klebsiella spp.). Counts were not different between the negative control and inoculant 2, but both were significantly greater than inoculant 1 at wk $1(P<0.01)$. At wk 2 , inoculant 2 displayed significantly greater gram-negative counts than either inoculant 1 or the negative control group $(P<0.01)$. Gram-negative bacterial counts were below the detectable limit for all treatment groups at wk 3. Conversely, all gram-negative counts were significantly lower at wk 1,2 , and 3 compared with wk $0(P<0.01)$. However, counts were lower than the detectable limit in all treatment groups at wk 1, 2, and 3 for corn samples, and no differences were seen between treatment groups.
A treatment $\times$ week interaction was significant for streptococcal counts on grass samples. Counts were significantly reduced in the negative control $(4.3 \pm 1.2$ $\log _{10} \mathrm{cfu} / \mathrm{g}$ of DM) compared with either inoculant 1 $\left(7.6 \pm 1.8 \log _{10} \mathrm{cfu} / \mathrm{g}\right.$ of DM $)$ or inoculant $2(7.0 \pm 0.1$ $\log _{10} \mathrm{cfu} / \mathrm{g}$ of DM) at wk $3(P<0.01)$. However, no differences were observed at wk 1 or 2 . The interaction remained significant for streptococcal counts on corn samples. At wk 1, counts were greater for inoculant 1 $\left(5.2 \pm 0.5 \log _{10} \mathrm{cfu} / \mathrm{g}\right.$ of DM) compared with inoculant $2\left(4.0 \pm 0.1 \log _{10} \mathrm{cfu} / \mathrm{g}\right.$ of DM; $\left.P<0.05\right)$, but no significant differences were observed between the negative control and either inoculant group. No differences were seen at wk 2 or 3 .

Inoculated grass samples displayed a greater count of enterococci compared with the negative control (1.2 \pm $1.2 \log _{10} \mathrm{cfu} / \mathrm{g}$ of DM) after the 3 -wk ensiling process. Additionally, inoculant $2\left(7.3 \pm 0.1 \log _{10} \mathrm{cfu} / \mathrm{g}\right.$ of DM) displayed a greater enterococci count than inoculant 1 $\left(4.2 \pm 1.8 \log _{10} \mathrm{cfu} / \mathrm{g}\right.$ of DM) at wk $3(P<0.01)$. No significant treatment differences were seen at wk 1 or 2 .

Enterococcal counts on corn samples were significantly greater at wk 0 compared with wk 1,2 , and 3 . At wk 1, counts in the negative control $\left(4.0 \pm 0.1 \log _{10}\right.$ $\mathrm{cfu} / \mathrm{g}$ of DM) and inoculant $1\left(3.9 \pm 0.1 \log _{10} \mathrm{cfu} / \mathrm{g}\right.$ of $\mathrm{DM}$ ) were not different from each other, but both were significantly greater than that of inoculant $2(2.8 \pm 0.1$ 
$\log _{10} \mathrm{cfu} / \mathrm{g}$ of DM; $\left.P<0.01\right)$. No treatment differences were observed at wk 2 . At wk 3 , enterococci counts were not different between inoculant $1\left(4.3 \pm 0.1 \log _{10}\right.$ $\mathrm{cfu} / \mathrm{g}$ of DM) and inoculant $2\left(4.0 \pm 0.1 \log _{10} \mathrm{cfu} / \mathrm{g}\right.$ of $\mathrm{DM})$. However, counts in both inoculant groups were significantly greater than that in the negative control $(P<0.05)$.

\section{DISCUSSION}

The final enterococcal count from grass at $3 \mathrm{wk}$ post-ensiling was $1.2 \pm 1.2 \log _{10} \mathrm{cfu} / \mathrm{g}$ of $\mathrm{DM}$ for the negative control and $5.8+1.0 \log _{10} \mathrm{cfu} / \mathrm{g}$ of DM for the treated groups. The final enterococcal counts from corn at 3 wk post-ensiling were $4.0 \pm 0.1 \log _{10} \mathrm{cfu} / \mathrm{g}$ of $\mathrm{DM}$ for the negative control and $4.4 \pm 0.1 \log _{10} \mathrm{cfu} / \mathrm{g}$ of DM for the treated groups. In both grass and corn samples, the inoculated groups showed greater enterococci counts at the end of the ensiling period than the negative controls. Counts from the current study are greater than those reported in a previous study, which also examined forage quality following inoculant application containing Enterococcus spp. (Cai, 1999). Following a 60-d ensiling period of alfalfa and guinea grass, levels of enterococci ranged from $10^{3}$ to $10^{5} \mathrm{cfu} / \mathrm{g}$ of fresh matter (Cai, 1999). It has been reported that accounting for DM percentage in bacterial enumeration results in a more conservative assessment for bacterial levels (Blok et al., 2000). Therefore, a shorter ensiling period and use of DM for calculation of bacterial counts may explain the differences observed between the current study and Cai (1999).

Despite a sharp decline in $\mathrm{pH}$, enterococci were detected in all grass and corn samples at the end of a 3 -wk ensiling period. Although it could be argued that a 3 -wk period is too short, previous research investigating bacterial inoculant effects on silage factors has used ensiling periods ranging from $3 \mathrm{wk}$ to 6 mo. These studies have reported viable lactic acid bacteria counts at the end of each experiment (Kent et al., 1989; Mackey and Hinton, 1990; Ashbell et al., 2001). Because a goal of this research was to be ultimately applicable to producers, the ensiling timeline was chosen to reflect probable on-farm conditions. This ensiling period also ensured the bacteria would experience the change in temperatures and $\mathrm{pH}$ often observed within the first 2 wk of fermentation.

Survival of streptococci on both forage crops, similar to that of enterococci, has contributed to the welldocumented similarity between the 2 genera. Mackey and Hinton (1990) observed similar results when examining enterococcal and streptococcal levels on inoculated animal feed. Similar growth characteristics were observed for enterococcal and streptococcal counts over a 4 -wk period following inoculation. Both enterococci and streptococci are able to survive at a wide range in $\mathrm{pH}$ values, including very low $\mathrm{pH}$. Data from the current study support the adaptability of streptococci and enterococci at $\mathrm{pH}$ values as low as 4.0.

All gram-negative bacterial counts were directly related to the change in $\mathrm{pH}$ over the 3 -wk ensiling period. In corn samples, $\mathrm{pH}$ decreased from 7.0 to 4.2 in the first week of the study and remained below that level for the remainder of the study. A decline in $\mathrm{pH}$ was also observed for grass samples; however, at wk 1 the average $\mathrm{pH}$ was 5.6, which allowed detectable levels of gram-negative bacteria in the negative control ( $\mathrm{pH} 5.6$ ) and inoculant 2 group ( $\mathrm{pH} 5.6$ ), but not in inoculant 1 (pH 5.4). Treatment differences were observed at wk 2 , with detectable levels of gram-negative bacteria in inoculant $2(\mathrm{pH} 6.4)$, but not inoculant $1(\mathrm{pH} 4.9)$ or the negative control ( $\mathrm{pH} 5.3$ ). At wk 3, gram-negative bacteria counts were lower than the detection limit and no significant treatment differences were observed $(\mathrm{pH}$ 5.2 ). These data suggest that a $\mathrm{pH}<5.4$ resulted in a lack of detectable gram-negative bacteria. Inoculant 1 reached that threshold by wk 1 , whereas the negative control reached that level by wk 2 , followed by inoculant 2 at wk 3. This change in bacterial viability was first reported by Gibson et al. (1958) who noted that gramnegative bacteria were the first to a decline, which was observed on $\mathrm{d} 1$ to 8 of ensiling.

These data suggest that silage inoculant use may increase the amount of enterococci and streptococci in grass and corn silages, which may lead to the consumption of heavily contaminated feed by dairy cows. Based on these results, we cannot conclude whether the resident or inoculant enterococci, or possibly both, contributed to this increase. However, we can conclude that the differences observed were due to inoculant application based on a comparison with the control group, which had no inoculant application.

Previous reports suggest that enterococci are unable to colonize the adult ruminant gastrointestinal tract (Devriese et al., 1992). Consequently, the consumption of these bacteria may lead to increased bacterial concentrations in fecal matter, which may serve as a source of contamination for the udder through the environment. However, this potential link has not been examined in dairy cattle and therefore further studies are warranted to examine the survivability of enterococci and streptococci through the gastrointestinal tract of dairy cows. We acknowledge the important role that silage inoculants play in dairy feed preservation and therefore do not suggest discontinued use. However, future studies may elucidate other candidate bacteria for inclusion in inoculants that would not increase the risk of intramammary infections in dairy cows. A lactic 
acid-producing bacterium in the silage inoculant that would not only drive the appropriate fermentation process but also possibly colonize the lower gastrointestinal tract of the dairy cow and act as a probiotic would be a possible candidate. Understanding the epidemiology and sources of enterococci and streptococci with regards to common farm management practices could lead to further knowledge regarding the control and transmission of these organisms.

\section{CONCLUSIONS}

These data suggest that the $\mathrm{pH}$ decrease was not affected by inoculant application on corn, but a treatment effect on grass was observed during a 3-wk ensiling process. Furthermore, counts of gram-negative bacteria were below the detection limit following a 3-wk ensiling process in grass and corn samples, regardless of inoculant application. However, both enterococci and streptococci were able to survive the ensiling process in both forage types. The application of a commercial inoculant increased enterococcal and streptococcal counts on grass compared with a negative control following the 3 -wk process, but this treatment difference was not observed for corn samples. The effect of increased enterococcal and streptococcal counts in feed on the health of the dairy cow remains unknown.

\section{ACKNOWLEDGMENTS}

The authors thank Wendy Wark and Joelle Eifert (Virginia Tech) for technical assistance and the Virginia Tech Dairy Center Staff for forage harvesting assistance. Advance VT (Blacksburg, VA) and Virginia Cooperative Extension (Blacksburg, VA) are gratefully acknowledged for financial support.

\section{REFERENCES}

Ashbell, G., T. Kipnis, M. Titterton, Y. Hen, A. Azrieli, and Z. G. Weinberg. 2001. Examination of a technology for silage making in plastic bags. Anim. Feed Sci. Technol. 91:213-222.

Blok, W. J., J. G. Lamers, A. J. Termorshuizen, and G. J. Bollen. 2000. Control of soilborne plant pathogens by incorporating fresh organic amendments followed by tarping. Phytopathology 90:253-259.

Cai, Y. 1999. Identification and characteristics of Enterococcus species isolated from forage crops and their influence on silage fermentation. J. Dairy Sci. 82:2466-2471.

Clewell, D. B. 1993. Bacterial sex pheromone-induced plasmid transfer. Cell 73:9-12.

Devriese, L. A., L. Laurier, P. De Herdt, and F. Haesebrouck. 1992. Enterococcal and streptococcal species isolated from faeces of calves, young cattle and dairy cows. J. Appl. Bacteriol. 72:29-31.
Gibson, T., A. C. Stirling, R. M. Keddie, and R. F. Rosenberger. 1958 Bacteriological changes in silage made at controlled temperatures. J. Gen. Microbiol. 19:112-129.

Gilmore, M. S. 2002. The enterococci-Pathogenesis, molecular biology, and antibiotic resistance. Page 439 in History, Taxonomy, Biochemical Characteristics, and Antibiotic Susceptibility Testing of Enterococci. R. R. Facklam, M. G. Carvalho, and L. M. Teixeira, ed. ASM Press, Washington, DC.

Harmon, R. J. 1994. Physiology of mastitis and factors affecting somatic cell count. J. Dairy Sci. 77:2103-2112.

Hogan, J. S., and K. L. Smith. 1997. Bacterial counts in sawdust bedding. J. Dairy Sci. 80:1600-1605.

Iversen, A., I. Kuhn, M. Rahman, A. Franklin, L. G. Burman, B. Olsson-Liljequist, E. Torell, and R. Mollby. 2004. Evidence for transmission between humans and the environment of a nosocomial strain of Enterococcus faecium. Environ. Microbiol. 6:55-59.

Jett, B. D., M. M. Huycke, and M. S. Gilmore. 1994. Virulence of enterococci. Clin. Microbiol. Rev. 7:462-478.

Kayser, F. H. 2003. Safety aspects of enterococci from the medical point of view. Int. J. Food Microbiol. 88:255-262.

Kent, B. A., M. J. Arambel, M. D. Winsryg, and J. L. Walters. 1989. Microbial inoculation of alfalfa haylage: Ensiling characteristics and milk production response when fed to early lactation dairy cows. J. Dairy Sci. 72:2325-2330.

Leng, Z., D. E. Riley, R. E. Berger, J. N. Krieger, and M. C. Roberts. 1997. Distribution and mobility of the tetracycline resistance determinant tetQ. J. Antimicrob. Chemother. 40:551-559.

Mackey, E. T., and M. Hinton. 1990. The survival of streptococci and enterococci in animal feed and on straw with particular reference to Streptococcus uberis. J. Appl. Bacteriol. 68:345-348.

Mannu, L., A. Paba, E. Daga, R. Comunian, S. Zanetti, I. Dupre, and L. A. Sechi. 2003. Comparison of the incidence of virulence determinants and antibiotic resistance between Enterococcus faecium strains of dairy, animal and clinical origin. Int. J. Food Microbiol. $88: 291-304$

Martinez-Murcia, A. J., and M. D. Collins. 1991. Enterococcus sulfureus, a new yellow-pigmented Enterococcus species. FEMS Microbiol. Lett. 64:69-74.

Olmsted, S. B., G. M. Dunny, S. L. Erlandsen, and C. L. Wells. 1994 A plasmid-encoded surface protein on Enterococcus faecalis augments its internalization by cultured intestinal epithelial cells. J. Infect. Dis. 170:1549-1556.

Paulsen, I. T., L. Banerjei, G. S. Myers, K. E. Nelson, R. Seshadri, T. D. Read, D. E. Fouts, J. A. Eisen, S. R. Gill, J. F. Heidelberg, H. Tettelin, R. J. Dodson, L. Umayam, L. Brinkac, M. Beanan, S. Daugherty, R. T. DeBoy, S. Durkin, J. Kolonay, R. Madupu, W. Nelson, J. Vamathevan, B. Tran, J. Upton, T. Hansen, J. Shetty, H. Khouri, T. Utterback, D. Radune, K. A. Ketchum, B. A. Dougherty, and C. M. Fraser. 2003. Role of mobile DNA in the evolution of vancomycin-resistant Enterococcus faecalis. Science 299:2071-2074.

Petersson-Wolfe, C. S., S. Adams, S. L. Wolf, and J. S. Hogan. 2008 Genomic typing of enterococci isolated from bovine mammary gland and environmental sources. J. Dairy Sci. 91:615-619.

Petersson-Wolfe, C. S., S. L. Wolf, and J. S. Hogan. 2009. Experimental challenge of bovine mammary glands with Enterococcus faecium during early and late lactation. J. Dairy Sci. 92:3158-3164.

Sahlström, L., V. Rehbinder, A. Albihn, A. Aspan, and B. Bengtsson 2009. Vancomycin-resistant enterococci (VRE) in Swedish sewage sludge. Acta Vet. Scand. 51:24

Schleifer, K. H., and R. Kilpper-Balz. 1984. Transfer of Streptococcus faecalis and Streptococcus faecium to the genus Enterococcus nom. rev. as Enterococcus faecalis comb. nov. and Enterococcus faecium comb. nov. Int. J. Syst. Bacteriol. 34:31-34.

Sobiraj, A., A. Kron, U. Schollmeyer, and K. Failing. 1997. Federal investigations on the distribution and in vitro resistance of udder pathogenic bacteria in the milk of cows with subclinical mastitis. Tierarztl. Prax. 25:108-115. 